\title{
Konstruksi Kekuasaan Politik Melalui Program Charity Show Media Televisi
}

\author{
Indra Setia Bakti a,1 , Khairul Amin b,2 \\ a,b Program Magister Sosiologi FISIP Universitas Malikussaleh, Lhokseumawe \\ Email: ${ }^{1}$ alqonz90@gmail.com ${ }^{2}$ indrasetiabakti@unimal.ac.id
}

\begin{tabular}{l}
\hline Informasi artikel \\
\hline Kata Kunci: \\
Nilai dan etika, pekerjaan \\
sosial, konseling, dan \\
pelayanan Hipnoterapi
\end{tabular}

\section{ABSTRAK}

Sebagai pendatang baru, Partai Perindo tentu berupaya menerapkan strategi khusus agar mampu bersaing dengan partai-partai lama yang sudah eksis terlebih dahulu dalam jagat politik Indonesia. Salah satunya melalui program charity show. Tingginya rating dan animo masyarakat menyaksikan tayangan tentang kehidupan orang miskin dalam berbagai program charity show selain menciptakan "ladang uang" bagi stasiun televisi dan pemiliknya juga menjadi sarana komunikasi politik. Ketika aktor politik menguasai media, maka jelas ada kepentingan yang juga turut dikomunikasikan dalam menjalankan media tersebut, termasuk sebagai corong politik kekuasaan untuk mendapatkan dukungan dari masyarakat pemilih. Demikian pula ketika Partai Perindo dideklarasikan , "aroma" bahwa HT bersama partainya akan menggunakan media yang berada di bawah kekuasaannya sebagai media komunikasi politik sangatlah jelas. Sinyal tersebut juga dapat dicermati dari dominasi HT beserta orang kepercayaannya di MNC Group dalam susunan Dewan Pengurus Pusat (DPP), Majelis Persatuan Partai, dan Mahkamah Partai Perindo. Artinya, program charity show ini tidak hanya memberi keuntungan bisnis yang sangat besar, tetapi juga media komunikasi politik, meningkatkan pencitraan di depan khalayak, dan membangun basis pemilih loyal dari keluarga prasejahtera penerima manfaat. Dalam menyelesaikan tulisan ini, penulis menggunakan pendekatan deskriptif kualitatif. Selanjutnya, data dalam tulisan ini bersumber dari hasil observasi, kajian literatur, serta sumber-sumber lainnya yang di anggap relevan dan kemudian dianalisis menggunakan perspektif teori pertukaran sosial Peter Blau.

\section{Keywords:}

Political Communication, Charity Shows, Social Exchange

\section{ABSTRACT}

As a newcomer, the Perindo Party seeks to implement a specific strategy in order to compete with other parties that have already existed in the Indonesian political contestation. One of these is charity show programs. The high rating and concern societies watching the lives of poor people in various charity programs show besides creating profits also become a means of political communication. When political actors control the media, it is clear that there are interests also communicated, including the political powers of the funnel to get support from voters. When the Perindo Party is declared, the "scent" that HT and his party would use the media under their control is very clear. These signals can also be observed from the dominance of HT's trusted people in the MNC Group in the composition of the Central Management Board Center, the Assembly of the Union Party and the court of Perindo party. That mean a charity program not only gives a very big business profit, but also the political media communication, enhance social branding in front of audiences, and build a base of loyal voters from poor family beneficiaries. To finishing this paper, the author uses a descriptive qualitative approach. The data in this article 
sourced from observations, studies of literature, and other sources considered relevant and then analyzed by the exchange theory of Peter Blau.

\section{PENDAHULUAN}

Tangis haru pecah di kediaman Bapak Sukarna tatkala ia dan keluarganya membaca sebuah kalimat di dalam map berlogo GTV. "Selamat! Rumah anda akan kami bedah". Sontak satu keluarga prasejahtera itu bersujud dan berpelukan satu sama lain. Mereka tidak menduga akan memperoleh berkah sebesar itu. Memiliki rumah layak huni merupakan angan yang jauh dari kenyataan bagi Bapak Sukarna, seorang buruh tani daun kemangi. Penghasilan pas-pasan dan tidak menentu membuat Bapak Sukarna sekeluarga terpaksa harus menjalani sulitnya roda kehidupan. Selama ini mereka hanya tinggal di sebuah gubuk kecil beralaskan tanah, berdinding tepas, dan beratapkan jerami. Bila turun hujan, keluarga itu harus rela tidur bersama genangan air. Bapak Sukarna ialah satu dari ratusan penerima berkah program Bedah Rumah yang ditayangkan oleh Global TV. Acara ini memiliki rating tinggi, ditayangkan pada jam tayang utama (prime time), dan diselingi oleh iklan yang sangat banyak.

Fenomena kemiskinan memang telah lama menjadi "wajah lain" Indonesia. Badan Pusat Statistik merilis angka kemiskinan per Maret 2018 sebesar 9,82 persen atau 25,95 juta jiwa (www.bps.go.id). Angka ini lebih besar dibandingkan jumlah konstituen PDI-P sebagai partai pemenang Pemilihan Umum Indonesia tahun 2014 sebesar 23.681.471 pemilih (www.kpu.go.id). Hadirnya program charity show yang "mengeksploitasi" kemiskinan mengindikasikan bahwa televisi dapat menjadi media komunikasi politik. Selalu ada framing dan agenda setting dalam setiap penampilan acara-acara televisi (Hamad, 2014: 8), tidak terkecuali program charity show.
Tingginya rating dan animo masyarakat menyaksikan tayangan tentang kehidupan orang miskin dalam berbagai program charity show menciptakan "ladang uang" bagi stasiun televisi dan pemiliknya. Pada tahun 2005 sebuah riset kuantitatif mencatat bahwa tiap spot iklan dengan durasi 30 detik dihargai Rp.18 juta. Sedangkan untuk program charity show "Bedah Rumah" biaya produksi per episode menghabiskan Rp.15 juta dan kemudian dijual kepada stasiun televisi dengan harga Rp. 30 juta per episodenya (Nosakros dkk, 2013: 181). Selain itu, program charity show ini juga menjadi sarana komunikasi politik yang efektif dan menjanjikan. Seperti halnya program charity show Bedah Rumah Global TV yang di sela-sela acara tersebut kerapkali ditampilkan Mars Perindo misalnya. Tampilnya Mars Perindo tersebut tentu dengan tujuan politis. Ariviyanti dan Nurfebiaraning (2017: 57) menilai hal tesebut sebagai suatu bentuk komunikasi politik dan sekaligus memuat pencitraan politik dengan maksud mengingatkan khalayak tentang siapa "sosok superhero" yang peduli kepada rakyat kecil dalam program charity show itu. Lebih lanjut, Hariyadi (2018: 126) menyatakan sebagai stasiun televisi yang sahamnya dimiliki oleh seorang petinggi Partai Perindo, tidak bisa ditampik bahwa media Global TV turut menjadi salah satu corong kepentingan politik HT dengan Partai Perindonya. Partai baru yang dirintisnya beberapa tahun lalu tentu membutuhkan panggung dalam perjuangan meraih kekuasaan, dan dalam rangka mewujudkan komitmen tersebut dibutuhkan perencanaan matang dalam membangun fondasi kekuasaan, basis pemilih, dan sasaran yang paling empuk tentu saja dari kalangan rumah tangga miskin.

Berdasarkan paparan singkat di atas, tulisan ini bertujuan untuk 
mendiskusikan tentang bagaimana strategi kekuasaan politik dibangun melalui program charity show di media televisi. Fokus yang dilihat dalam hal ini adalah relasi pertukaran yang dibangun Partai Perindo melalui program Bedah Rumah Global TV sebagai bentuk konstruksi kekuasaan politik. Hal ini menjadi menarik mengingat media sebagai pilar kelima demokrasi memiliki pengaruh terhadap pembentukan opini publik, terlebih HT sebagai pemilik media sekaligus pemimpin partai.

\section{METODE}

Dalam tulisan ini, penulis menggunakan pendekatan deskriptif kualitatif. Metode ini digunakan agar diperoleh gambaran keadaan secara mendalam. Menurut Lehman (dalam Yusuf, 2014: 62) penelitian deskriptif kualitatif adalah salah satu jenis penelitian yang bertujuan mendeskripsikan secara sistematis, faktual, dan akurat mengenai fakta dan fenomena secara detail. Isaac dan Micheil (1980) menyatakan bahwa tujuan penelitian deskriptif adalah: "to discribe systematically the fact and characteristics of a given population or area of interest".

Oleh karena itu, pendekatan deskriptif kualitatif ini digunakan untuk memberikan jawaban secara sistematis terhadap masalah yang diteliti, serta untuk mendapatkan informasi yang lebih mendalam terhadap suatu fenomena yang diteliti. Selanjutnya, data dalam tulisan ini bersumber dari hasil observasi, kajian literatur, serta sumber-sumber lainnya yang dianggap relevan dan kemudian dianalisis menggunakan persepektif teori pertukaran sosial Peter Blau.

\section{HASIL DAN PEMBAHASAN}

Media televisi selain berperan sebagai media informasi, hiburan, kontrol sosial, dan penghubung wilayah secara geografis, juga berfungsi sebagai media komunikasi politik. Hal ini sesuai dengan fungsi media yaitu memberikan informasi, mendidik, menghibur, dan mempengaruhi khalayak. Keempat fungsi tersebut dapat membentuk kepribadian masyarakat baik dari sisi kognitif, afektif, maupun behavioral (Kuswandi, 1996: 99). Bahkan dalam posisinya sebagai suatu institusi informasi, media dipandang sebagai faktor yang paling menentukan dalam prosesproses perubahan sosial budaya dan politik (Sobur, 2004: 31).

Dalam konteks Indonesia pasca Reformasi, media menjadi salah satu pilar demokrasi yang "merdeka" dari pengekangan selama masa Orde Baru, maka tidak berlebihan kemudian ketika sejumlah pakar menaruh harapan besar kepada pers agar benar-benar memainkan perannya sebagai pilar demokrasi dengan menjalankan fungsinya sebagai pengawas aktivitas eksekutif, legislatif, dan yudikatif. Namun dalam perkembangannya, pesimisme mulai muncul ketika aktoraktor politik mulai menguasai saham sejumlah media massa nasional yang berakibat pada independensi media-media tersebut dipertanyakan. Rasa pesimisme ini tentu beralasan karena ketika aktor politik menguasai media, maka jelas ada kepentingan yang juga turut disuarakan dalam menjalankan media tersebut. Meski hal ini bukan sesuatu yang salah dalam iklim demokrasi tetapi jika media yang seharusnya menyuarakan nilai-nilai demokrasi berubah menjadi corong politik kekuasaan elit tertentu maka akan mengancam demokrasi itu sendiri.

Saat ini kita mengenal beberapa media massa nasional telah dikuasai oleh elit politik kelas satu negeri ini. Kita pun dapat menyaksikan bahwa kepemilikan media tersebut juga mempengaruhi kualitas informasi yang disampaikan. Sebut saja misalnya kasus Pilpres 2014 silam yang secara nyata melahirkan dikotomi antar dua media besar (Metro TV \& TV ONE) yang ada di negeri ini. Keberpihakan politik media tersebut jelas sekali terlihat dari konten-konten yang ditampilkan di layar kaca, dan tentu bagi yang mengetahui siapa pemilik media tersebut dengan sangat mudah menebak afiliasi politiknya. Demikian pula dengan 
program charity show yang dibahas dalam tulisan ini.

Pada tanggal 7 Februari 2015 dilaksanakan deklarasi Partai Perindo. Pada momen tersebut, HT memberi sinyal bahwa Perindo adalah "partai modern" yang akan dikelola secara profesional. Posisi HT dengan latar belakang sebagai pengusaha membuatnya mendesain struktur Dewan Pengurus Pusat (DPP) Partai Perindo layaknya sebuah perusahaan (lihat, Tirto.id, 2018. "Perindo, Partai
Politik Rasa MNC"). Hal ini tentu mengindikasikan bahwa keterlibatan Global TV sebagai media konstruksi kekuasaan HT tampak jelas. Sinyal tersebut juga dapat dicermati dari dominasi kaki-tangan HT di MNC Group dalam susunan Dewan Pengurus Pusat (DPP). HT dengan Perindonya telah menempatkan "orang-orang dekatnya" di MNC Group untuk menduduki posisi penting pada Majelis Persatuan Partai dan Mahkamah Partai Perindo.

Tabel 1. Partai Perindo Rasa MNC Group

\begin{tabular}{|c|l|l|l|}
\hline No. & \multicolumn{1}{|c|}{ Nama } & \multicolumn{1}{|c|}{ Jabatan di MNC Group } & \multicolumn{1}{|l|}{ Jabatan di DPP Partai Perindo } \\
\hline 1 & $\begin{array}{l}\text { Donny } \\
\text { Ferdiansyah }\end{array}$ & $\begin{array}{l}\text { Executive Assistance to CEO } \\
\text { MNC }\end{array}$ & Wakil Sekjen III \\
\hline 2 & Ajun Damayanti & Sekretaris Global Mediacom & Wakil Sekjen IV \\
\hline 3 & $\begin{array}{l}\text { Angela } \\
\text { Tanoesudibyo }\end{array}$ & $\begin{array}{l}\text { Direktur Operasional Global } \\
\text { TV }\end{array}$ & Wakil Sekjen VII \\
\hline 4 & Hendry Suparman & Direktur MNC Corporation & Bendahara Umum \\
\hline 5 & $\begin{array}{l}\text { Stien Maria } \\
\text { Schouten }\end{array}$ & Komisaris Independen MNC & Bendahara I \\
\hline 6 & Eva Mutia & MNC Finance & Bendahara III \\
\hline 7 & Syafril Nasution & Direktur PT Global Mediacom & Ketua Bidang Organisasi \\
\hline 8 & Sururi Alfaruq & Direktur Utama Koran Sindo & Ketua Bidang Litbang dan IT \\
\hline 9 & $\begin{array}{l}\text { Arya Mahendra } \\
\text { Sinulingga }\end{array}$ & Direktur Pemberitaan MNC & $\begin{array}{l}\text { Ketua Bidang Media dan } \\
\text { Komunikasi Massa }\end{array}$ \\
\hline 10 & $\begin{array}{l}\text { A. Wishnu } \\
\text { Handoyono }\end{array}$ & Komisaris MNC Securitas & $\begin{array}{l}\text { Ketua Bidang UMKM dan } \\
\text { Koperasi }\end{array}$ \\
\hline 11 & Susi Meilina & $\begin{array}{l}\text { Direktur Utama MNC } \\
\text { Securitas }\end{array}$ & Ketua Bidang Perekonomian \\
\hline 12 & $\begin{array}{l}\text { Christophorus } \\
\text { Taufik }\end{array}$ & Direktur PT Global Mediacom & ketua Bidang Hukum dan HAM \\
\hline 13 & $\begin{array}{l}\text { Wina Armada } \\
\text { Sukardi }\end{array}$ & $\begin{array}{l}\text { Komisaris Independen PT. } \\
\text { MNC Tbk. }\end{array}$ & $\begin{array}{l}\text { Ketua Bidang Perburuhan dan } \\
\text { Ketenagakerjaan }\end{array}$ \\
\hline 14 & $\begin{array}{l}\text { David Fernando } \\
\text { Audy }\end{array}$ & CEO MNC & $\begin{array}{l}\text { Majelis Persatuan Partai } \\
\text { (Sekretaris) }\end{array}$ \\
\hline 15 & Hendry Suparman & Direktur MNC Corporation & Majelis Persatuan Partai \\
\hline 16 & $\begin{array}{l}\text { Liliana } \\
\text { Tanoesudibyo }\end{array}$ & $\begin{array}{l}\text { Komisaris PT MNC } \\
\text { Investama Tbk }\end{array}$ & Majelis Persatuan Partai \\
\hline 17 & Syafril Nasution & Direktur PT Global Mediacom & Mahkamah Partai (Ketua) \\
\hline 18 & $\begin{array}{l}\text { Christophorus } \\
\text { Taufik }\end{array}$ & Direktur PT Global Mediacom & Mahkamah Partai (Sekretaris) \\
\hline 19 & M. Budi Rustanto & Direktur MNC Land & Mahkamah Partai \\
\hline 66 & Agus Mulyanto & Direktur MNC Play & Mahkamah Partai \\
\hline
\end{tabular}


sedikit atau banyak berdampak pada eksistensi media televisi swasta di bawah payung MNC Group. Tidak dapat dipungkiri bahwa media-media tersebut ikut masuk ke dalam arus politik praktis dan nyata-nyata menunjukkan keberpihakan kepada HT beserta afiliasi kekuasaannya. Dapur redaksi menjadi korban yang diobok-obok agar sejalan dengan kepentingan politik HT. Iklan Partai Perindo sangat mendominasi disuguhkan di sela acara televisi. Bahkan program-program berita seperti Lintas INews rutin menampilkan pemberitaan kegiatan Partai Perindo.

Sebagai partai baru, kondisi tersebut secara sosiologis dapat dipahami sebagai strategi Partai Perindo agar dapat bersaing dengan partai-partai lama yang sudah eksis terlebih dahulu dalam jagat politik Indonesia. Belum lagi dengan ketentuan parliamentary threshold pada Pemilu 2019 memaksa partai politik baru seperti Perindo untuk bergerak cepat agar minimal tidak terdegradasi pada kontestasi pemilu berikutnya. Lalu ada hal yang tidak kalah penting, Pemilu 2019 merupakan tonggak sejarah yang menandai partisipasi aktif klan HT dalam politik praktis di Indonesia. Sejumlah anggota keluarga inti HT bertarung dalam kontestasi Pemilu 2019 diantaranya istri (LT) dan ketiga putrinya (AT, JT, dan VT).

Pada musim Pemilu, berbagai janji begitu mudah diumbar dengan maksud menyedot perhatian pemilih. Namun apatisme masyarakat mulai menyeruak ketika berbagai janji urung ditepati. Pada kondisi inilah, HT dengan korporasi yang dikuasainya mengambil peluang untuk membangun basis pemilih partainya. Kaya raya dan menguasai saham beberapa stasiun televisi nasional, sosok HT memberi banyak keuntungan bagi perkembangan Partai Perindo. Beberapa media di bawah kendali MNC Group dengan cukup massif menampilkan sosok HT sebagai orang kaya dermawan di layar kaca dengan berbagai momentum. Publikasi cuma-cuma dan terus-menerus melalui media yang dikuasaunya ini ditanamkan ke dalam memori kolektif khalayak. Bahkan tak jarang HT berkunjung dan memberi bantuan materi ke beberapa pondok pesantren di Indonesia dalam rangka menyemai citra positif di kalangan pemilih Islam.

Hal ini tentunya dilakukan dalam rangka menangkal pandangan negatif terhadap status yang disandangnya yang kurang menguntungkan secara politik. Pada berbagai daerah di Indonesia telah lama berkembang prasangka (prejudice) terhadap warga negara Indonesia keturunan etnis Tionghoa. Ada kesan pemimpin politik harus pribumi. Selain itu, status agama minoritas yang dianutnya diperparah oleh situasi politik identitas belakangan ini yang mulai ramai menjadi polemik pasca insiden kasus penistaan agama oleh BTP (Ahok) yang menyulut digelarnya silaturahmi akbar 212 serta memantik beraneka produksi dendam dan ujaran kebencian. Kemarahan kolektif sebagian massa yang membawa simbol Islam kepada BTP punya potensi untuk disalurkan kepada HT dan partai yang dinahkodainya.

Meskipun demikian, "uang dan kuasa atas media" digunakan untuk menutupi banyak kelemahan HT dan Perindonya. Harapannya, budi baik seseorang dapat berbicara lebih daripada ideologi dan identitasnya. Melalui program charity show Global TV, HT sebagai elit yang berkepentingan meraup suara untuk partainya menjajakan "sinterklasisme". Tujuannya menanamkan investasi kekuasaan kepada calon konstituen keluarga prasejahtera yang ditolong bahkan jauh hari sebelum masa kampanye tiba. Dibungkus oleh kegiatan bisnis, program charity show sangat berpotensi sebagai tindakan start kampanye. Ada sesuatu yang dipertukarkan secara politik via media yang dikuasai dan program yang ditayangkan.

\section{Analisis Relasi Pertukaran Sosial}

Aktor utama relasi pertukaran sosial dalam konstruksi kekuasaan politik 
yang dilakukan melalui program charity show adalah Global TV (bersama krunya) dan keluarga penerima manfaat. Terdapat pula aktor-aktor lain yang mendukung berjalannya relasi sosial ini, diantaranya HT (pemilik Global TV), penonton (audience), dan perusahaan-perusahaan yang memasang iklan. Kemudian ada pula aktor-aktor yang meraih keuntungan politik secara tidak langsung dari berjalannya relasi pertukaran sosial ini, yaitu Partai Perindo dan HT sendiri.

Melihat pada motif tindakannya, terdapat aktor rasional seperti Global TV, Partai Perindo, dan HT. Aktor-aktor ini bertindak berdasarkan perhitungan ekonomi politik dalam proses relasi pertukaran sosial tersebut. Di sisi lain, terdapat pula aktor spontan (operant actor) yang tindakannya dapat dibaca melalui analisis psikologi-perilaku, diantaranya keluarga miskin penerima manfaat beserta komunitas di sekitarnya, dan sebagian pemirsa (audience) setia program charity show Global TV.

Relasi pertukaran sosial melibatkan sumberdaya (resource) yang dipertukarkan, yakni sesuatu yang dimiliki aktor yang dihargai oleh aktor lain dan nilainya sangat tergantung dari masingmasing aktor. Bagi keluarga miskin penerima manfaat, bantuan langsung dalam bentuk materi adalah sesuatu yang lebih bernilai dan diharapkan. Uang, sembako, atau tempat tinggal bahkan jauh lebih dihargai daripada janji kampanye dan program politik jangka panjang yang belum jelas wujudnya. Sementara bagi HT dan Partai Perindo, sumberdaya yang dibutuhkan ialah dukungan politik dalam pemilu, termasuk dalam pemungutan suara tahun 2019.

Dalam konteks tersebut, sumberdaya tentunya menimbulkan biaya (cost) yang dikeluarkan aktor dan dampak (outcome) bagi mitra pertukaran. Ketika Tim kreatif Global TV mengeluarkan biaya yang tidak sedikit dalam proses produksi program-program charity show, maka diharuskan menghasilkan profit yang bombastis pula. Dalam sekali tayang misalnya, program Bedah Rumah rata-rata diselingi oleh sekitar 100 slot iklan, sehingga dalam sekali tayang, program Bedah Rumah mampu meraup keuntungan hingga milyaran rupiah. Selain itu, secara "terselubung" program charity show ini juga terkait pada mobilisasi dukungan keluarga penerima manfaat terhadap partai yang berafiliasi dengan Global TV. Harapannya terbangun hubungan pertukaran sosial yang berkembang dalam struktur saling ketergantungan.

Secara sederhana pertukaran dalam konteks ini dapat dilakukan secara langsung (direct exchange) atau tidak langsung (generalized/indirect exchange). Pertukaran yang terjadi secara tidak langsung dapat dilihat dalam bagan berikut ini:

Gambar 1. Struktur Pertukaran Tidak Langsung

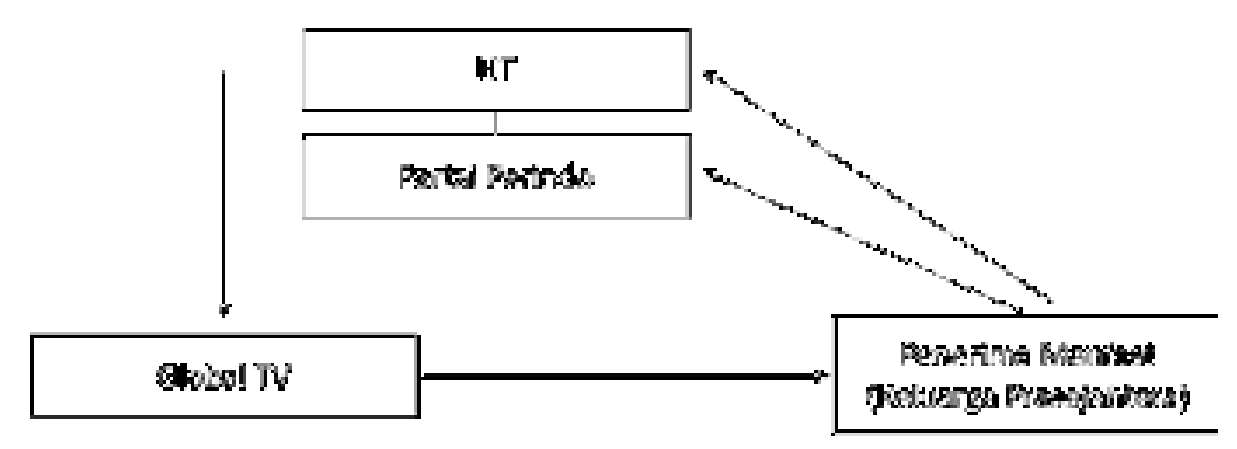


Dalam bagan tersebut terdapat lebih dari satu set hubungan pertukaran diad dimana proses pertukaran menggambarkan bagaimana interaksi berlangsung dalam struktur pertukaran. Struktur pertukaran tidak langsung tersebut kemudian membentuk jaringan pertukaran diantara aktor-aktor yang terlibat. Secara sederhana, jaringan pertukaran yang tercipta melalui program charity show dapat digambarkan dalam bagan berikut:

Gambar 2. Jaringan Pertukaran

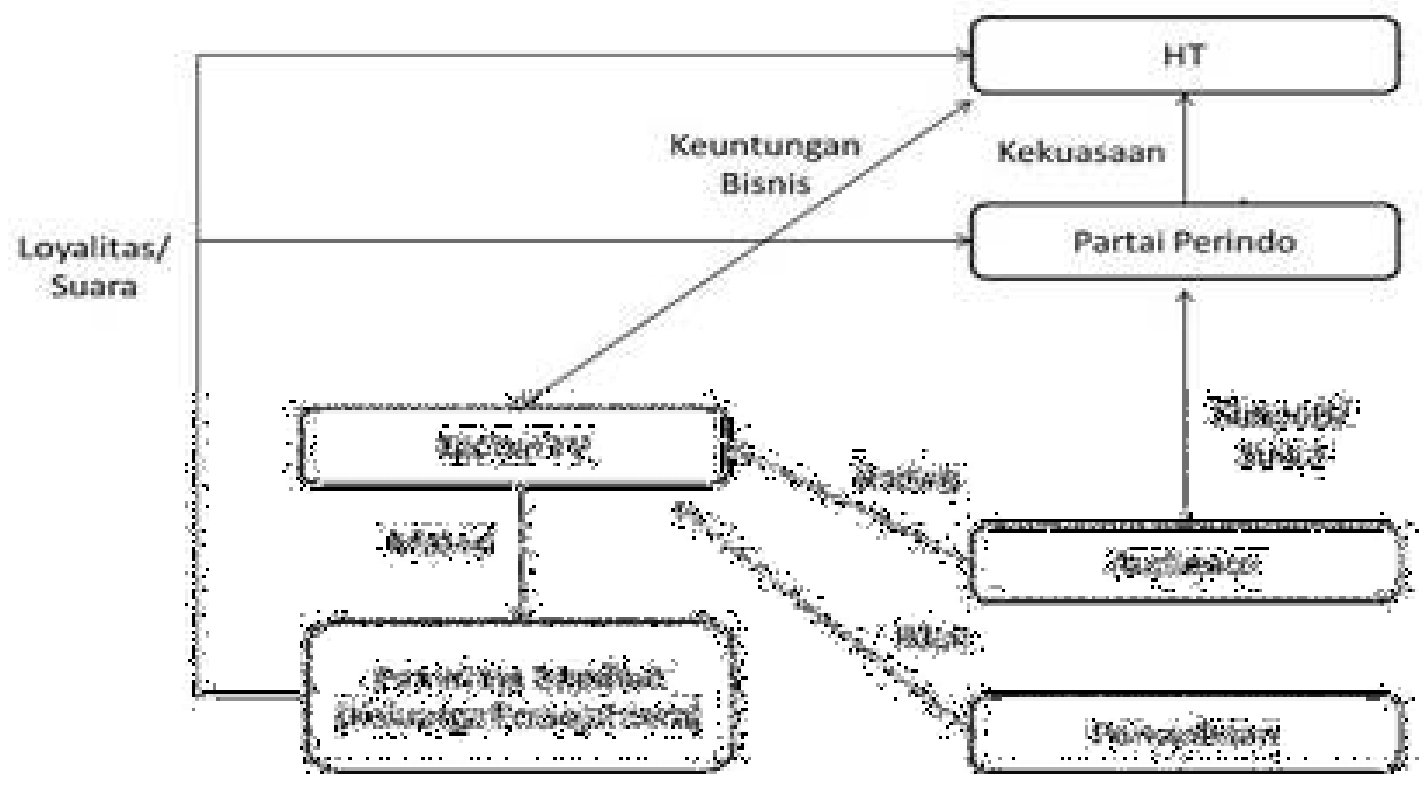

Bagan di atas menggambarkan relasi pertukaran yang terjadi dalam program charity show tidak hanya berkaitan dengan aspek material saja, tetapi juga berkaitan dengan konstruksi kekuasaan politik. Selain keuntungan ekonomi, tampak pula mobilisasi politik yang menjadi bagian dari relasi pertukaran tersebut. Ada sosok yang kemudian sengaja ditampilkan sebagai pahlawan bagi orang miskin dan sosok tersebut terikat dengan partai politik tertentu. Bagi para penerima manfaat program berserta para penontonnya secara sosiologis dikonstuksi untuk kemudian menerima hal tersebut sebagai suatu realitas objektif dimana Partai Perindo beserta HT adalah sosok dermawan yang mampu hadir menyelesaikan persoalan kemiskinan masyarakat. Artinya, ada narasi yang tersembunyi berupa agenda setting dalam konteks relasi pertukaran tidak langsung yang tercipta melalui program charity show tersebut, yaitu menciptakan simpati dan loyalitas pemilih melalui framing yang tampak dari suatu program televisi.

Pada sisi lain, tekait relasi pertukaran dan konstruksi kekuasaan yang dibangun melalui media televisi dapat pula dilihat dari tindakan sosial yang lahir dari fenomena charity show. Motif tindakan sosial dalam kehidupan sosial pada dasarnya dipengaruhi oleh berbagai macam faktor dan fenomena, temasuk oleh sesuatu yang dapat dipertukarkan yang kemudian menciptakan suatu relasi pertukaran. Ada yang seimbang dan ada pula yang tidak seimbang. Relasi pertukaran yang seimbang diharapkan dapat menghasilkan transaksi dan negosiasi. Sementara relasi pertukaran yang tidak seimbang justeru dikhawatirkan menciptakan dominasi dan kooptasi. Apa yang sudah ditanam pada saatnya tiba akan ditagih kembali. "Tidak 
ada makan siang gratis", demikian peribahasa yang sering kita dengan dalam kehidupan sehari-hari, yang bisa jadi bermakna bahwa selalu ada motif di balik sebuah tindakan sosial.

Bila memperhatikan reaksi penerima manfaat setelah diberikan sejumlah materi dalam suatu program charity show menunjukkan besarnya berkah (nilai) yang mereka terima. Mungkin seumur hidup penerima manfaat belum pernah bertemu dengan seseorang yang menyedekahkan materi dalam jumlah besar sehingga muncul reaksi-reaksi seperti menangis, bersujud, berangkulan, pingsan, mencium tangan host, bahkan memegang lutut host yang notabene lebih muda usianya. Penampakan ini menjadi bumbu-bumbu yang menambah kadar kenikmatan menyaksikan programprogram charity show. Kerumunan tetangga sekitar dan pemirsa televisi pun tidak jarang terharu, turut meneteskan air mata menyaksikan reaksi emosional dari para penerima manfaat.

Fenomena ini menunjukkan bahwa melalui program charity show ini, HT dan MNC Group berpotensi melakukan proses penanaman hutang budi terhadap keluarga penerima manfaat. Ada konstruksi kekuasaan yang dibangun melalui peristiwa yang ditampilkan. Dalam program Bedah Rumah, misalnya, setelah host bermalam mencicipi rasa kemiskinan, keesokan harinya host mengajak keluarga penerima manfaat jalan-jalan ke tempat wisata, berbelanja ke mall, berobat ke dokter, menginap di hotel mewah, dan makan di restoran mahal ketika proses rekonstruksi rumah tengah berlangsung. Secara sosiologis, kegiatan senang-senang ini dapat menjadi memori yang tidak mudah dilupakan oleh mitra pertukaran. Terlebih ketika proses rekonstruksi rumah sudah selesai dilakukan, host menggiring keluarga prasejahtera itu untuk melihat kejutan rumah impian baru untuk pertama kalinya. Disaksikan komunitas masyarakat sekitar, tirai yang menutupi rumah baru itu disibak, dan reaksi emosional menyeruak akan melahirkan makna tentang siapa sosok yang berada di balik semua fenomena tersebut. Belum lagi ketika rumah baru itu dibuka, sudah tersedia pula perabotan-perabotan mahal seperti sofa, televisi, kulkas, lemari, springbed, meja belajar, kompor gas, kipas angin yang sengaja ditampakkan kepada penerima manfaat dan tanpa disadari telah membentuk buah simpati pemirsa yang menyaksikan tayangan tersebut.

Belum lagi misalnya dalam penyerahan bantuan tersebut ditampilkan pula sosok yang telah memberikan bantuan yang notabene adalah pemilik media dan keluarganya. Dalam konteks politik, hal ini membangun narasi yang kuat dalam benak penerima manfaat beserta para pemirsa bahwa sosok tersebut layak untuk dipilih dalam kontestasi politik yang sedang terjadi karena kepeduliannya terhadap masyarakat miskin. Kondisi ini secara psikologis dan secara sosial menggiring pemaknaan bahwa ada sosok yang begitu berjasa, sehingga melalui fenomena inilah konstruksi kekuasaan terbangun.

\section{KESIMPULAN}

Program charity show yang ditampilkan melalu media televisi dalam konteks politik pada dasarnya memainkan peran yang cukup penting. Terutama dalam proses membangun basis pemilih loyal. Ketika aktor politik menguasai media maka jelas ada kepentingan yang juga turut disuarakan, termasuk sebagai corong politik kekuasaan untuk mendapatkan dukungan dari masyarakat pemilih. Demikian pula ketika Partai Perindo dideklarasikan, "aroma" bahwa HT bersama partainya tersebut akan menggunakan media yang berada di bawah kekuasaannya sebagai media komunikasi politik sangatlah jelas.

Relasi pertukaran yang terjadi dalam program charity show yang ditampilkan melalui media televisi di bawah kuasa HT tidak hanya berkaitan dengan aspek material, tetapi juga berkaitan dengan konstruksi kekuasaan 
politik (fungsi laten). Selain keuntungan ekonomi yang diperoleh dari berlangsungnya program, ada pula mobilisasi politik dan konstruksi kekuasan yang terjadi. Terdapat narasi tersembunyi dalam konteks relasi pertukaran tidak langsung yang tercipta melalui program charity show tersebut, yaitu menciptakan simpati dan loyalitas pemilih melalui framing yang tampak dari suatu program televisi. Program charity show tampil sebagai program yang berpihak pada rakyat miskin dan sekaligus menjadi srategi yang tidak hanya memberi keuntungan bisnis, namun juga meningkatkan pencitraan di depan khalayak, membangun basis pemilih loyal dari keluarga prasejahtera penerima manfaat yang sangat besar serta menghindari tuduhan praktik politik uang. Fenomena yang disuguhkan melalui program charity show beserta bumbubumbunya menciptakan relasi pertukaran yang bersifat patron-klien. Hal ini secara psikologis dan secara sosial berhasil menggiring pemaknaan bahwa ada sosok yang begitu berjasa.

\section{DAFTAR PUSTAKA}

Abercrombie, Nicholas, Stephen Hill, dan Bryan S. Turner. 2010. Kamus Sosiologi. Yogyakarta: Pustaka Pelajar.

Ariviyanti, Betari Chintya dan Sylvie Nurfebiaraning. 2017. Analisis Aktivitas Pembetukan Citra Politik Hary Tanoesoedibjo: Studi Semiotika Peirce pada Iklan TV Perindo "Mars Perindo Versi 2". Channel 5(1):48-58.

Badan Pusat Statistik (16 Juli 2018). Persentase Penduduk Miskin Maret 2018 Turun Menjadi 9,82 Persen. Diakses 17 Maret 2019. https://www.bps.go.id/pressreleas e/2018/07/16/ 1483/persentase- penduduk-miskin-maret-2018turun-menjadi-9-82-persen.html

Damsar. 2010. Pengantar Sosiologi Politik. Jakarta: Kencana.

Duverger, Maurice. 2010. Sosiologi Politik. Jakarta: Rajawali Pers.

Gaffar, Afan. 1991. Hubungan PatronClient dan Konsekuensinya terhadap Lahirnya Pengusaha Indonesia: Review Buku Dr. Yahya Muhaimin. UNISIA 10(XI.IV):83-90.

Gatara, A.A. Said dan Moh. Dzulkiah Said. 2007. Sosiologi Politik : Konsep dan Dinamika Perkembangan Kajian. Bandung: Pustaka Setia.

Greenberg, Martin S. 1980. A Theory of Indebtedness, dalam Kenneth J. Gergen, Martin S. Greenberg, dan Richard H. Willis. 1980. Social Exchange: Advances in Theory and Research. New York and London: Plenum Press.

Hamad, Ibnu. 2004. Konstruksi Realitas Politik dalam Media Massa: Sebuah Studi Critical Discourse Analysis terhadap Berita-berita Politik. Jakarta: Granit.

Harga.web.id (17 September 2018). Update Harga Pasang Iklan di Televisi Nasional 2018. Diakses pada 19 Maret 2019. https://harga.web.id/berapakahharga-pasang-ikan-di-televisi-inidia-jawabannya.info

Hariyadi, Taufan. 2018. Runtuhnya Pilar Demokrasi, Politik Kuasa Media Partai Perindo di MNC Group. DiMCC Conference Proceeding 1:110-130.

Komisi Pemilihan Umum (22 Juli 2014). Rekapitulasi Hasil Pemilu Tahun 2014. Diakses 18 Maret 2019. https://www.kpu.go.id/index.php/ pages/detail/2014/282 
Kuswandi, Wawan. 1996. Komunikasi Massa: Sebuah Analiasis Media Televisi. Jakarta: Rineka Cipta.

Molm, Linda D. 1997. Coercive Power in Social Exchange. Cambridge: Cambridge University Press.

Nosakros, Arya dkk. 2013. Komodifikasi Kemiskinan dalam Televisi Indonesia: Studi Komparatif antara Program "Jika Aku Menjadi" di Trans TV dengan Program "Bedah Rumah" di RCTI. Jurnal Komunikasi KAREBA 2(2): 175-185

Philipus, Ng. dan Nurul Aini. 2006. Sosiologi dan Politik. Jakarta: PT. RajaGrafindo Persada.

Poloma, Margaret M. 2004. Sosiologi Kontemporer. Jakarta: PT RajaGrafindo Persada.

Ritzer, George dan Douglas J. Goodman. 2011. Teori Sosiologi: Dari Teori Sosiologi Klasik Sampai Perkembangan Mutakhir Teori Sosial Postmodern. Bantul: Kreasi Wacana.

Sobur, Alex. 2004. Analisis Teks Media: Suatu Pengantar untuk Analisis Wacana, Analisis Semiotik, dan Analisis Framing. Bandung: PT. Remaja Rosdakarya.

Sunarto, Kamanto. 2004. Pengantar Sosiologi. Jakarta: Lembaga Penerbit Fakultas Ekonomi Universitas Indonesia.

Sutrisno, Mudji dan Hendar Putranto. 2005. Teori-Teori Kebudayaan. Yogyakarta : Kanisius.

Suyanto, Bagong dan M. Khusna Amal (ed.). 2010. Anatomi dan Perkembangan Teori Sosial. Malang: Aditya Media Publishing.

Tirto.id (6 Juli 2018). Perindo, Partai Politik Rasa MNC. Diakses pada
19

Maret

2019.

https://tirto.id/perindo-partai-

politik-rasa-mnc-cNvZ

Yusuf, Muri. 2014. Metode Penelitian: Kuantitatif, Kualitatif dan Penelitian Gabungan. Jakarta: Kencana. 